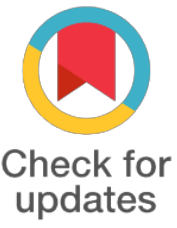

${ }^{*}$ For correspondence:

kalyani.neuro@gmail.com

Competing interests: The authors declare that no competing interests exist.

Received: 2017-04-27

Accepted: 2017-05-30

Published: 2017-09-05

Copyright The Author(s) 2017. This article is published with open access by BioMedPress (BMP).

This article is distributed under the terms of the Creative Commons Attribution License (CC-BY 4.0) which permits any use, distribution, and reproduction in any medium, provided the original author(s) and the source are credited.

\section{Potential strategies to improve Temozolomide/ radiation therapy of malignant gliomas by targeting glycolytic energy metabolism}

\author{
Kalyani Thakur, Mr. Sai Shyam, Dr. Vijay Kalia
}

Research Associate, National Centre for Disease Informatics and Research ICMR Complex, Nirmal Bhawan, Kannamangala Bangalore, Karnataka 562110, India

\section{Abstract}

The current standard treatment of Malignant Gliomas includes surgery, followed by Temozolomide (TMZ) - Radiotherapy. It leads to increased survival as compared to radiotherapy alone. However, haematological toxicities are also increased by the combination treatments. Therefore, it is important to carry out further preclinical studies, to develop more effective treatment for these tumors. 2-Deoxy-D-Glucose (2DG), an inhibitor of glycolytic energy metabolism, has been shown earlier to differentially inhibit repair processes, growth and survival of cancer cells. It has been tolerated very well in combination with radiotherapy in clinical trials on Malignant Gliomas. In this study, we investigated the effects of combination of clinically relevant concentrations of 2-DG $(0.5 \mathrm{mM}$ and $1 \mathrm{mM})$ and TMZ $(2 \mu \mathrm{M}$ and $5 \mu \mathrm{M}) \pm$ Radiation (1Gy) on cell proliferation, total cellular damage (TCD) and colony formation in an established Glioblastoma cell line (U251MG), and primary cultures derived from malignant glioma tumor pieces. The monolayer cultures were grown on cover slips and stained with Acridine Orange $(0.002 \%)$ after drug treatments and irradiation, for the study of cellular damage and death. Exponentially growing cells were exposed to drugs and Gamma irradiation. Drugs were removed $4 \mathrm{hrs}$ after irradiation and cultures were processed for different assays of cell death and damage. Our results showed that combination of 2-DG with $T M Z \pm$ Radiation significantly inhibited the cell proliferation up to 6 days. The TCD was significantly increased by the combination of drugs in primary as well as in established cell line. Cell proliferation as measured by MTT assay showed that drugs \pm radiation significantly reduced proliferation response. Cell survival inhibition after combination of TMZ+2-DG+Gamma $(2 \mu M+0.5 \mathrm{mM}+1 \mathrm{~Gy})$ showed more than additive effects. These results suggest that targeting glycolytic energy metabolism by agents such as 2-DG can enhance the efficacy of TMZ+Radiation Therapy for Malignant Gliomas, without increasing toxic side effects.

\section{Keywords}

Malignant Gliomas, Temozolomide, 2-DG, Radiotherapy, Metabolism

Funding

\section{References}

